\title{
Micrometeorological observations of a microburst in southern Finland
}

\author{
Leena Järvi • Ari-Juhani Punkka • David M. Schultz • Tuukka Petäjä • \\ Harri Hohti · Janne Rinne · Toivo Pohja · Markku Kulmala • Pertti Hari • \\ Timo Vesala
}

Received: 10 August 2006 / Accepted: 4 June 2007 / Published online: 14 July 2007

(C) Springer Science+Business Media B.V. 2007

\begin{abstract}
On the afternoon of 3 July 2004 in Hyytiälä (Juupajoki, Finland), convective cells produced a strong downburst causing forest damage. The SMEAR II field station, situated near the damage site, enabled a unique micrometeorological analysis of a microburst with differences above and inside the canopy. At the time of the event, a squall line associated with a cold front was crossing Hyytiälä with a reflectivity maximum in the middle of the squall line. A bow echo, rear-inflow notch, and probable mesovortex were observed in radar data. The bow echo moved west-north-west, and its apex travelled just north of Hyytiälä. The turbulence data were analysed at two locations above the forest canopy and at one location at sub-canopy. At 1412 EET (Eastern European Time, UTC+2), the horizontal and vertical wind speed increased and the wind veered, reflecting the arrival of a gust front. At the same time, the carbon dioxide concentration increased due to turbulent mixing, the temperature decreased due to cold air flow from aloft and aerosol particle concentration decreased due to rain scavenging. An increase in the number concentration of ultra-fine particles $(<10 \mathrm{~nm})$ was detected, supporting the new particle formation either from cloud outflow or due to rain. Five minutes after the gust front (1417 EET), strong horizontal and downward vertical wind speed gusts occurred with maxima of 22 and $15 \mathrm{~m} \mathrm{~s}^{-1}$, respectively, reflecting the microburst. The turbulence spectra before, during and after the event were consistent with traditional turbulence spectral theory.
\end{abstract}

Keywords Aerosol particles $\cdot$ Convective storm $\cdot$ Microburst $\cdot$ Micrometeorology $\cdot$ Trace gases

L. Järvi (凶) · D. M. Schultz · T. Petäjä · J. Rinne · M. Kulmala · T. Vesala

Department of Physical Sciences, University of Helsinki, P.O. Box 64, Helsinki 00014, Finland

e-mail: leena.jarvi@helsinki.fi

A.-J. Punkka · D. M. Schultz · H. Hohti

Finnish Meteorological Institute, P.O. Box 503, Helsinki 00101, Finland

T. Pohja

Hyytiälä Forestry Field Station, University of Helsinki, Hyytiäläntie 124, Korkeakoski 35500, Finland

P. Hari

Department of Forest Ecology, University of Helsinki, P.O. Box 27, Helsinki 00014, Finland 


\section{Introduction}

On the afternoon of 3 July 2004, an area of scattered thunderstorms occurred in southern Finland. One of the convective cells produced a small downburst, known as a microburst, that was detected at the SMEAR II (Measuring Forest Ecosystem-Atmosphere Relations) field station in Hyytiälä, where a large array of micrometeorological instrumentation is operated continuously (Vesala et al. 1998; Hari and Kulmala 2005). The main microburst damage track was around $10 \mathrm{~m}$ long and approximately $20 \mathrm{~m}$ wide, and trees fell mostly to the south-west, although areas outside the main damage track also experienced occasional forest damage. A microburst passing through a well-equipped observation site provides a unique opportunity to study high-resolution turbulence data, trace gas and total aerosol particle concentrations, and aerosol size spectra during an extreme weather event.

Severe thunderstorms mainly occur in Finland from June to August, and where lightning and heavy rain are sometimes accompanied by downbursts, and tornadoes are occasionally observed. The short lifetime and small size of microbursts and tornadoes make direct observations difficult. Because eyewitnesses are rare in sparsely populated areas of Finland, these phenomena are mostly detected only by their damage track on the earth's surface, supported by radar imagery (e.g. Punkka et al. 2006).

Although much previous research has been performed on severe convective storms and microbursts, we are not aware of any other study that has presented high frequency $(>10 \mathrm{~Hz})$ data from a microburst. To our knowledge, Sherman (1987) is the only known report of vertical velocity data from a microburst (at an instrumented tower in Brisbane, Australia), but no other micrometeorological analysis was made in that study. Our observations are novel in that we are able to link the meteorological observations to measurements of turbulence characteristics, trace gas (water vapour, carbon dioxide, and ozone) concentrations, and aerosol particle concentrations before, during, and after the microburst.

The aim of this study is to investigate the micrometeorological features of the 3 July 2004 microburst. Three-dimensional high-frequency wind measurements are analyzed, including comparisons between above-canopy and sub-canopy measurements. Trace gas concentrations, total aerosol particle concentrations and aerosol particle size spectra are shown, providing an example of their behaviour in extreme weather conditions. Turbulence spectra of horizontal and vertical wind speed components before, during and after the microburst event are studied, and dissipation rates and turbulent kinetic energy are calculated. Radar data are analyzed to investigate the larger mesoscale conditions associated with the microburst. These observations, along with the damage-track analysis, allowed us to classify the event as a microburst, instead of a tornado.

The measurement site, instrumentation and methodology applied in this study are introduced in Sect. 2. Section 3 presents the results and discussion, beginning with the synoptic and mesoscale overview in Sect. 3.1. Section 3.2 describes the local weather conditions on 3 July 2004 and Sect. 3.3 presents the micrometeorological analysis of the gust front and microburst and relates these observations to existing conceptual models of convective systems. Section 3.4 presents the trace gas and aerosol particle measurements and Sect. 3.5 presents the turbulence spectra, turbulent kinetic energy (TKE) and its dissipation calculations before, during and after the microburst event. Finally, Sect. 4 provides conclusions.

\section{Measurements and methods}

The microburst occurred in Hyytiälä, Juupajoki (southern Finland), $210 \mathrm{~km}$ north of Helsinki (Fig. 1a). The SMEAR II field station $\left(61^{\circ} 51^{\prime} \mathrm{N}, 24^{\circ} 17^{\prime} \mathrm{E}, 181 \mathrm{~m}\right.$ above sea level) is 
located close to the Hyytiälä Forestry Field Station (University of Helsinki). A large number of diverse meteorological measurements are collected at the SMEAR II station and more detailed description about the station and its measurements are presented in Vesala et al. (1998) and Hari and Kulmala (2005). The station is surrounded mainly by a 42 -year-old Scots pine stand with an average tree height of $16 \mathrm{~m}$ in 2004, and the forest damage site is about $200 \mathrm{~m}$ south-west of the measuring station (Fig. 2). A standard SYNOP weather station (Finnish Meteorological Institute, Hyytiälä, WMO 05174) is located $450 \mathrm{~m}$ south-west from the SMEAR II station. The C-band weather radar used in the study (Finnish Meteorological Institute) is situated at Ikaalinen $\left(61^{\circ} 46^{\prime} \mathrm{N}, 23^{\circ} 04^{\prime} \mathrm{E}, 154 \mathrm{~m}\right.$ above sea level), $65 \mathrm{~km}$ west of Hyytiälä.

The SMEAR II station has three eddy-covariance systems recording turbulence data. Two systems above the canopy are at the same height of $23 \mathrm{~m}$ and are separated by a horizontal distance of $30 \mathrm{~m}$. These are henceforth referred as locations A and B (Fig. 2). The third system is sub-canopy, below the foliage at $3 \mathrm{~m}$, about $20 \mathrm{~m}$ south from location B. The above-canopy systems include 3-dimensional acoustic anemometers Solent 1012R2 and Solent HS1199 (Gill Instruments Ltd., Lymington UK) and the sub-canopy sonic anemometer is a Metek USA-1 (Metek GmbH, Germany). For all turbulence measurements, the measuring frequency is $10.4 \mathrm{~Hz}$. The clocks of the two above-canopy instruments were synchronized but differences of some seconds may exist between these and the sub-canopy measurements.

At location A, wind speed and direction were measured at heights of 73.0 and $8.4 \mathrm{~m}$ with a 2-dimensional ultrasonic anemometer (Adolf Thies GmbH, Göttingen, Germany), whereas temperature was measured at heights of $67.2 \mathrm{~m}$ and $8.4 \mathrm{~m}$ with a Pt-100 resistance thermometer. Also at location A, pressure was measured at ground level with a digital pressure indicator (DPI260, Druck, Williston, VT), and dew-point temperature was measured at a height of $23 \mathrm{~m}$ (General Eastern Hygro E4, Billerica, MA, USA). At location B, rainfall was collected above the canopy at a height of $18 \mathrm{~m}$ with a rain collector (ARG-100). In addition, precipitation recorded at the local SYNOP weather station (Finnish Meteorological Institute, WMO 05174) was used.

Carbon dioxide and water vapour concentrations were measured with a fast-response gas analyser LI-6262 (Li-Cor Inc., Lincoln, NE, USA), and an ozone analyser TEI 49C (Thermo Electron Corporation, Waltham, MA, USA) and a condensation particle counter (CPC) (TSI 3010, Shoreview, MN, USA) were used to measure ozone and total particle concentrations, respectively. These measurements were made at location $A$ at a height of $23 \mathrm{~m}$. Aerosol particle size distribution was observed by means of twin differential mobility particle sizer (DMPS) systems (Aalto et al. 2001), and ion size distribution was measured with a balanced scanning mobility analyzer (BSMA, Airel Ltd., Estonia). The DMPS technique is based on the electrical classification of particles combined with the concentration measurement by the CPC. One system measured sizes from 3 to $10 \mathrm{~nm}$ (TSI 3025, Shoreview, MN, USA) and the other from 10 to $500 \mathrm{~nm}$ (TSI 3010, Shoreview, MN, USA). Both of the size distribution measurements were situated in a cabin north of location A (Fig. 2), with the air drawn into the cabin from an outside height of $2 \mathrm{~m}$.

The 10-min average data are used for pressure, wind speed and temperature for the whole of 3 July 2004 to obtain information on the general weather conditions. A more detailed meteorological analysis was made for 1400-1430 EET (Eastern European Time, UTC+2) when the event was observed. Mean or instantaneous values for wind speed, wind direction and vertical wind speed in all locations are used. For gas and total aerosol particle concentrations, 15-sec average values are analyzed, and 1-min average pressure at ground level, the 15 -sec average temperature and the 1-min average dew point temperature are presented. 
(a)
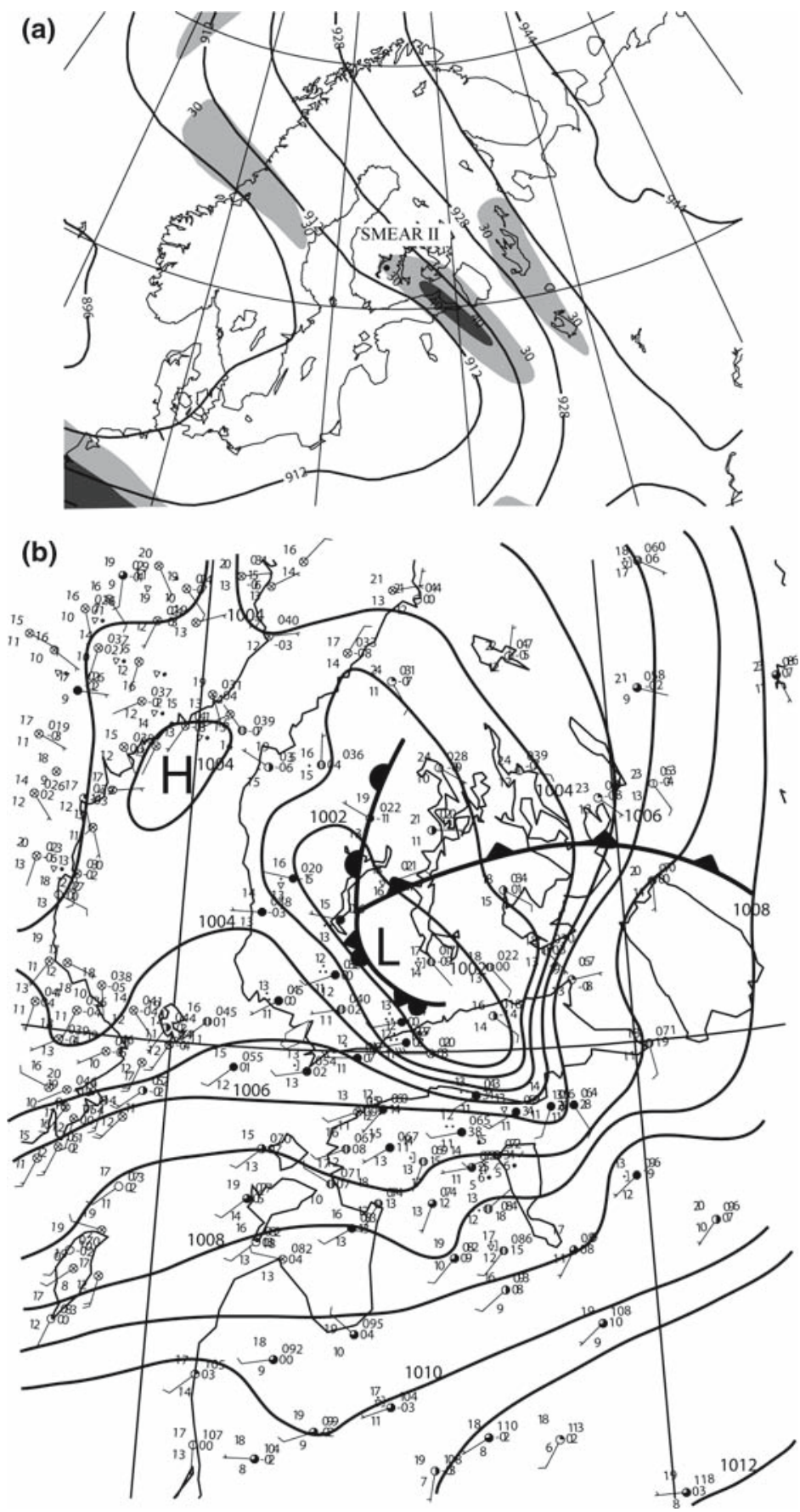

Fig. 1 (a) Constant pressure analysis from European Centre for Medium-Range Weather Forecasts model analysis at $300 \mathrm{hPa}$ at 0200 EET 3 July $2004(E E T=U T C+2)$ : isohypses (solid lines every 80 dam) and isotachs (shaded every $10 \mathrm{~m} \mathrm{~s}^{-1}$ for speeds greater than $30 \mathrm{~m} \mathrm{~s}^{-1}$ ). (b) Surface SYNOP observation map at 1400 EET 3 July 2004: manually analyzed isobars every $1 \mathrm{hPa}$, with standard frontal analysis 


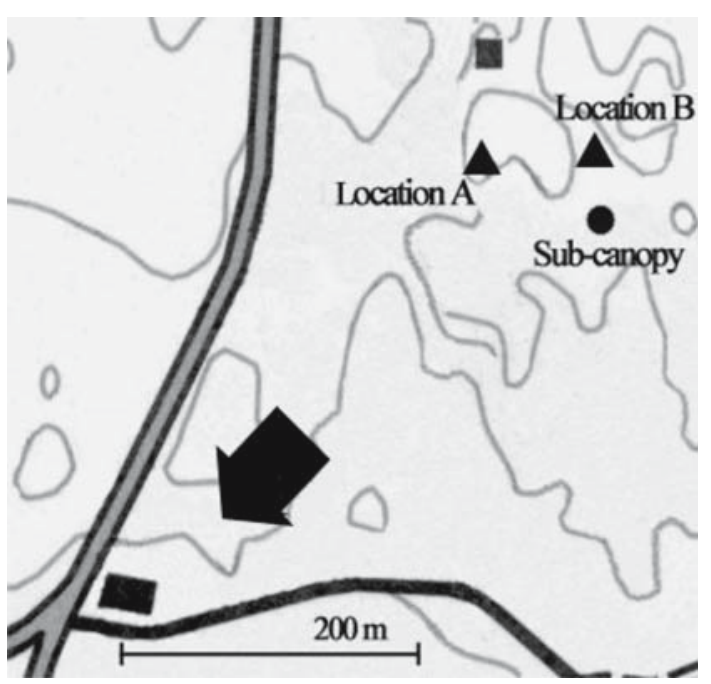

Fig. 2 Location of the forest damage and measuring locations at the SMEAR II station at Hyytiälä. The black arrow shows the location of the damage site and the direction of fallen trees. The triangle represents the above-canopy locations A and B and the circle stands for sub-canopy measurements. The square represents the instrument cabin, and the rectangle represents an un-instrumented barn. The grey lines represent schematic topography. Other lines represent roads

Finnish Meteorological Institute radar data, with SYNOP observation maps and European Centre for Medium-Range Weather Forecasts numerical model analyses, are used to analyze the synoptic and mesoscale environment of the microburst.

The atmospheric spectra were calculated using a fast Fourier transform for 5- to 10-min sections, after having been de-trended and Hamming windowed (Kaimal and Kristensen 1991). A two-dimensional coordinate rotation (i.e., $u_{\text {rot }}$ is the wind component rotated to the direction of the mean wind and $v_{\text {rot }}$ is the wind component directed perpendicular to the mean wind) was applied for the spectral calculations (Kaimal and Finnigan 1994). Turbulence dissipation rate $\varepsilon$ was calculated according to the inertial dissipation technique

$$
\varepsilon=\frac{2 \pi}{\bar{U}} \sum_{j=1}^{n}\left[\frac{f_{j}^{5 / 3} S_{u_{i}}\left(f_{j}\right)}{\alpha_{i}}\right]^{3 / 2},
$$

$S_{u i}\left(f_{j}\right)$ is the frequency spectrum of wind component $u_{i}$ at frequency $f_{j}$ ( $n$ is the number of frequencies) and $\alpha_{i}=0.53$ is the Kolmogorov constant. (Piper and Lundquist 2004). Turbulence dissipation was calculated only for $u_{\text {rot }}$. The turbulent kinetic energy, TKE, was calculated according to

$$
\mathrm{TKE}=0.5\left(\overline{u^{\prime 2}}+\overline{v^{\prime 2}}+\overline{w^{\prime 2}}\right)
$$

where $u$ and $v$ are horizontal wind components directed east and north, respectively, and $w$ is the vertical wind component (e.g. Holton 1992). The overbar denotes a 15 -sec time average and the prime refers to instantaneous turbulent fluctuations around the average. 


\section{Results and discussion}

\subsection{Synoptic and mesoscale overview}

On 3 July 2004, an elongated upper-level short-wave trough, extending from southern Norway to the Baltic countries, moved north (Fig. 1a). Two minor surface depressions were situated over Estonia and east of Finland (not shown). During the morning, the depression over Estonia started to occlude and, in the afternoon, was south-east of Hyytiälä. At 1400 EET, a warm front lay just west of Hyytiälä, and a cold front approached the microburst area (Fig. 1b). At Hyytiälä, the surface temperature was close to $20^{\circ} \mathrm{C}$, with a dew-point temperature of around $15^{\circ} \mathrm{C}$, which combined with the nearest environmental sounding (Jyväskylä, 0800 EET 3 July 2004, not shown) produced convective available potential energy of about $500 \mathrm{~J} \mathrm{~kg}^{-1}$.

During the morning of 3 July, a rain area was observed in south-western Finland (not shown). A line of convective cells arrived at the southern Finnish coastline by 1200 EET and moved north-west, though the exact interaction between these convective storms and the cold front remains unknown. The leading edge of the line reached Hyytiälä around 1330 EET. Unlike other mesoscale convective systems (e.g., Parker and Johnson 2000), the maximum in radar reflectivity factor was located in the middle of the line (Fig. 3a-c). About $30 \mathrm{~min}$ before the microburst, the patterns in radar reflectivity factor showed the development of a bow echo, a rear-inflow jet and a rear-inflow notch. These radar signatures moved just north of Hyytiälä at 1415 EET (Fig. 3b), and are all considered important indicators of convective systems producing strong surface winds (e.g., Fujita 1979; Przybylinski and DeCaire 1985; Smull and Houze 1987; Przybylinski 1995; Wakimoto et al. 2006). Within a mesoscale convective system, a rear-inflow jet may advect dry mid-level air into the convective system, leading to evaporative cooling of precipitation, negative buoyancy, convective downdrafts, and the bowing of the convective line (e.g., Atkins and Wakimoto 1991). The rear-inflow notch, a channel of weak radar echoes pointing from the stratiform precipitation region toward the convective line, is the indication of the evaporation of the precipitation by the rear-inflow jet. Upon passing over Hyytiälä at 1412 EET, this convective line produced the microburst.

Recent numerical modelling (Weisman and Trapp 2003; Trapp and Weisman 2003) and observational studies (Atkins et al. 2004, 2005; Wheatley et al. 2006; Wakimoto et al. 2006) have shown that the most intense straight-line winds within bow echoes are frequently associated with low-level mesovortices. In the United States, where the majority of the bow echoes move to the east or south-east, the most severe wind damage is observed north or north-west (left) of the bow echo apex in close association with mesovortices (e.g., Wheatley et al. 2006). Interestingly, the 3 July 2004 microburst occurred about $10 \mathrm{~km}$ left of the apex. Examination of the Ikaalinen radar radial velocities at 1415 EET (Fig. 3d) showed a couplet of inbound and outbound velocities, with the northern flank of the possible vortex travelling over Hyytiälä at the time of the microburst. The difference between the inbound and outbound velocities was $15-20 \mathrm{~m} \mathrm{~s}^{-1}$, and the distance between the maximum and minimum radial velocity was about $5 \mathrm{~km}$, both comparable to previous studies (e.g., Atkins et al. 2004, 2005). However, closer examination of the structure and evolution of the possible mesovortices and other radar signatures is beyond the scope of this study.

Downdrafts in thunderstorms are believed to be generated by evaporative cooling, precipitation loading, and precipitation drag (e.g., Wakimoto 2001; Choi 2004). Processes affecting the amount of negative buoyancy of the descending air parcels govern the intensity of the subsequent downdraft. Thus, melting, evaporation, and sublimation of hydrometeors lead to colder and denser downdraft air, which accelerates towards the surface. The cooling effects 

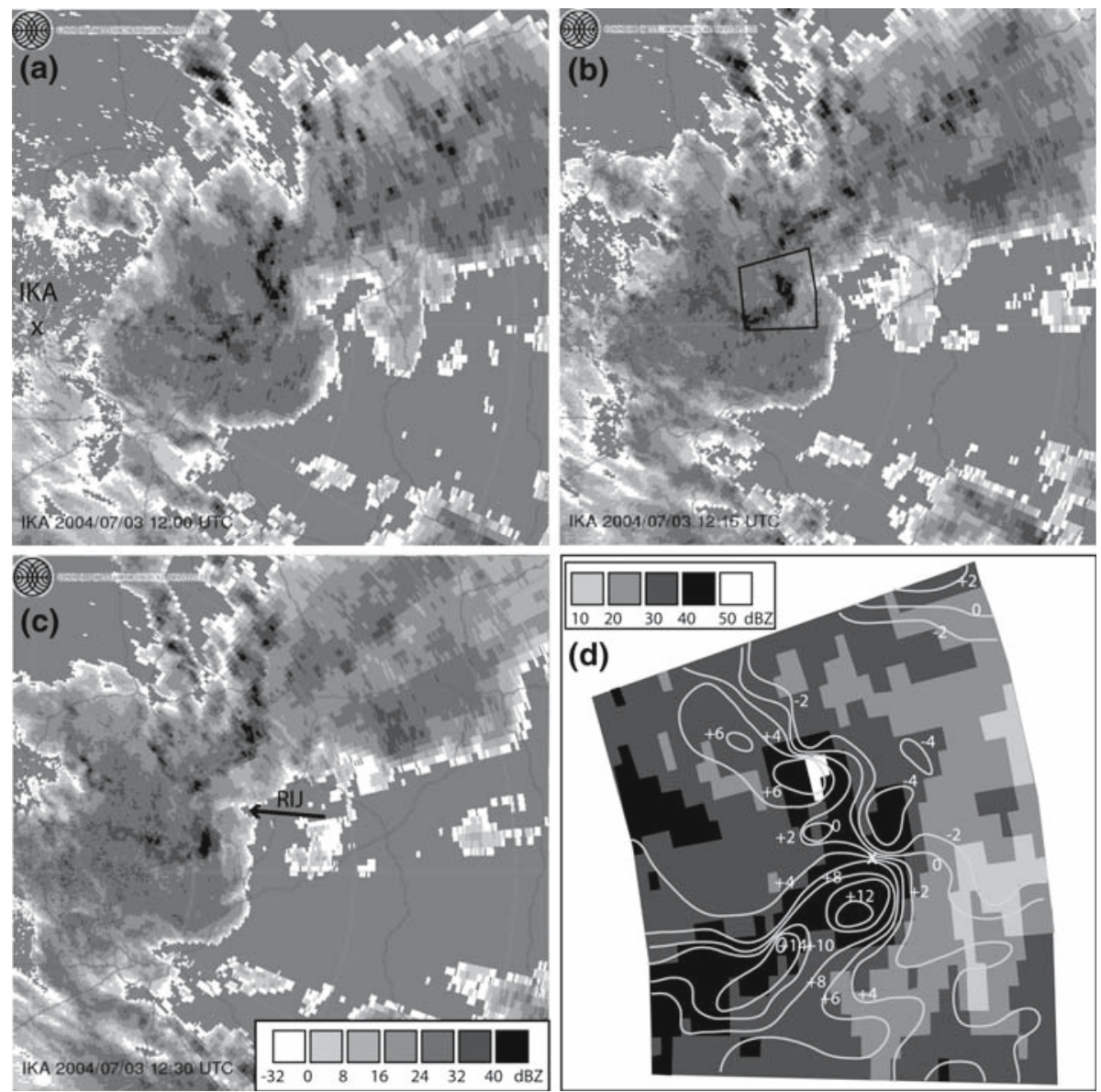

Fig. 3 Radar reflectivity factor (dBZ, shaded) from the Ikaalinen radar (labelled IKA in panel a) at (a) 1400 EET 3 July 2004, (b) 1415 EET with inset box, and (c) 1430 EET with location of rear-inflow jet (RIJ) shown by the arrow. (d) inset location from b) showing 1415 EET storm-relative radial velocity field (white solid lines every $2 \mathrm{~m} \mathrm{~s}^{-1}$, positive values away from radar) overlain on radar reflectivity factor ( $\mathrm{dB} Z$, shaded), and the location of the wind damage area marked with white $\mathrm{X}$

associated with these phase changes usually offset the adiabatic warming of descending air. In addition, Ogura and Liou (1980) showed that convective downdrafts effectively transport horizontal momentum vertically. Therefore, convective cells developing in moderate to strong low- and mid-level flow should aid in the production of microbursts associated with strong winds.

These synoptic and mesoscale observations suggest that the convection in the Hyytiälä case occurred in an environment of modest convective available potential energy and moderate vertical shear of the horizontal wind. Such an environment is characteristic of convective systems formed under strong synoptic forcing. In such cases, the lack of abundant instability can be compensated for by greater wind shear to produce strong surface winds (e.g., Evans and Doswell 2001). 


\subsection{Local weather conditions on 3 July 2004}

On 3 July 2004, the surface pressure decreased from $984 \mathrm{hPa}$ to $979 \mathrm{hPa}$ from 0000 to 2000 EET at location A at the SMEAR II station (not shown). Two clear peaks at approximately 0500 EET and 1415 EET were observed, with the latter appearing at the same time as the thunderstorm moved over Hyytiälä. The maximum air temperature was reached around 1200 EET, after which the temperature decreased sharply, $4.5^{\circ} \mathrm{C}$ within $1.5 \mathrm{~h}$ (not shown). The minimum temperatures of $13^{\circ} \mathrm{C}$ and $13.5^{\circ} \mathrm{C}$ at heights of 67.2 and $8.4 \mathrm{~m}$, respectively, coincided with the maximum pressure (around 1415 EET). The decrease of the temperature and the pressure jump indicate the arrival of the microburst event. The mean wind speed was less than $3 \mathrm{~m} \mathrm{~s}^{-1}$ at the lower level $(8.4 \mathrm{~m})$ throughout the day, but at the higher level $(73 \mathrm{~m})$, wind speed reached $13 \mathrm{~m} \mathrm{~s}^{-1}$, coinciding with the pressure peak and local minimum temperature (not shown). Between 0800 EET 3 July 2004 and 0800 EET 4 July 2004, the measured rainfall was $30.3 \mathrm{~mm}$. During the thunderstorm, the maximum precipitation intensity (with 15-min resolution) was $3.5 \mathrm{~mm} \mathrm{~h}^{-1}$ between 1400 and 1415 EET (not shown).

\subsection{Micrometeorological features}

More detailed examination of the period when the microburst occurred (1400-1430 EET) indicated a more complex structure. Before the event, the instantaneous wind speed above the forest was about $2 \mathrm{~m} \mathrm{~s}^{-1}$ and near-zero at the sub-canopy, and the wind direction was from the north-north-west (Fig. 4). The vertical wind velocity was a few tens of $\mathrm{mm} \mathrm{s}^{-1}$ (Figs. 5 and 6), and temperature and dew-point temperature at location $\mathrm{A}$ were $18^{\circ} \mathrm{C}$ and $13.2^{\circ} \mathrm{C}$, respectively (Fig. 7). At 1405 EET, the pressure started to increase from $980.2 \mathrm{hPa}$ (Fig. 7) and one minute later, the wind slowly began turning to the north-east. The gust front reached the measurement site at 1412 EET, detected as an increase in the horizontal and vertical wind speeds at all three measurement locations (Figs. 4-6). Half a minute later, the pressure reached a maximum of $981.4 \mathrm{hPa}$, and both temperature and dew-point temperature experienced a small increase of $0.5^{\circ} \mathrm{C}$ (Fig. 7). Within two minutes at $1413 \mathrm{EET}$, both temperature and dew-point temperature fell by $2.5^{\circ} \mathrm{C}$ on arrival of the cold air (Fig. 7). Other gust-front studies (e.g., Charba 1974; Mueller and Carbone 1987) have observed this pressure peak and wind shift together with the temperature fall, consistent with our measurements. The pressure increase and wind shift prior to the gust front is believed to be caused by the dynamic effects of the temperature difference between the air masses (Figure 1 in Droegemeier and Wilhelmson 1987).

A windy and gusty period ensued between 1412 and 1418 EET (Figs. 4-6). Two peaks in horizontal wind speed were evident at location A, the first $\left(19 \mathrm{~m} \mathrm{~s}^{-1}\right)$ after 1413 EET and the second $\left(22 \mathrm{~ms}^{-1}\right)$ at 1417 EET (Fig. 4a). The peak wind speed values at location $\mathrm{B}$ of $21 \mathrm{~m} \mathrm{~s}^{-1}$ ) and at sub-canopy of $9 \mathrm{~m} \mathrm{~s}^{-1}$ occurred at the same time as the second wind speed maximum at location A (Fig. 4). During this 7-min period of gusty winds, the vertical wind speed fluctuated between -15 and $+10 \mathrm{~m} \mathrm{~s}^{-1}$ at location $\mathrm{A}$, between -9 and $+9 \mathrm{~m} \mathrm{~s}^{-1}$ at location $\mathrm{B}$ and between -1.6 and $+1.8 \mathrm{~m} \mathrm{~s}^{-1}$ in the sub-canopy (Fig. 5). Examining the vertical wind speed at location A with a higher temporal resolution revealed a brief episode of strong downward motion around 1417 EET (Fig. 6). This downward motion was also seen at location $\mathrm{B}$ and in the sub-canopy, although the strongest downward motion was measured a half a minute before at location B (not shown). Comparable descent in microbursts has been seen by others (e.g., Proctor 1988; Hjelmfelt et al. 1989). The horizontal wind speed maximum and the downward motion 5-min after the gust front at 1417 EET indicated the microburst arriving at the measuring station. The time lag of five minutes between the first 


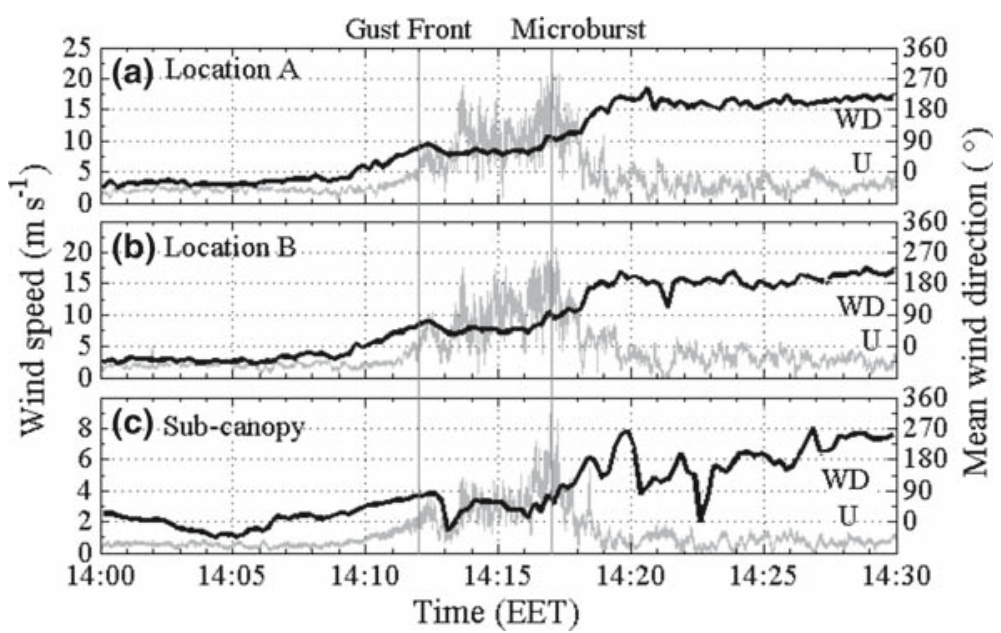

Fig. 4 Time series at SMEAR II station for 1400-1430 EET: instantaneous wind speed ( $\mathrm{ms}^{-1}$, thin grey lines) and 15-sec average wind direction ( ${ }^{\circ}$, thick black lines) measured at (a) location A, (b) location B and (c) sub-canopy. Note the different velocity scale of the sub-canopy plot. The vertical lines represent the arrival of the gust front and microburst, respectively

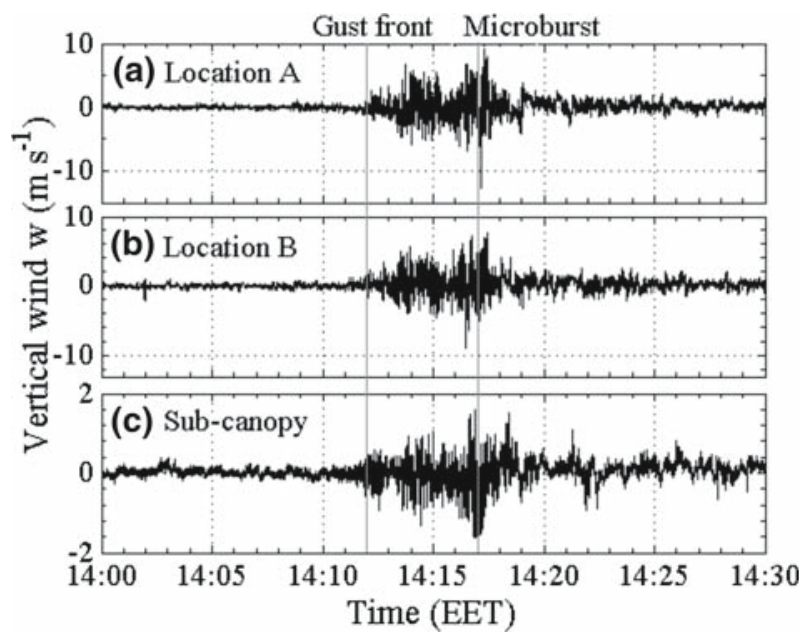

Fig. 5 Time series at SMEAR II station for 1400-1430 EET: instantaneous vertical wind speed ( $\left.\mathrm{m} \mathrm{s}^{-1}\right) \mathrm{mea}^{-}$ sured at (a) location A, (b) location B and (c) sub-canopy. Note the different velocity scale of the sub-canopy plot. The vertical lines represent the arrival of the gust front and microburst, respectively

gusty winds (gust front) and the maximum wind speed (microburst) has also been observed by Takayama et al. (1997).

Between the gust front and the microburst, the pressure experienced a minimum and started to increase, along with temperature and dew-point temperature, at 1416 EET at the same time as the strengthening microburst (Fig. 7). The wind veered toward the east preceding the gust front and during the microburst (Fig. 4), and a second pressure maximum occurred just after the highest wind speed values (Fig. 7). After the windy episode, both the horizontal and 


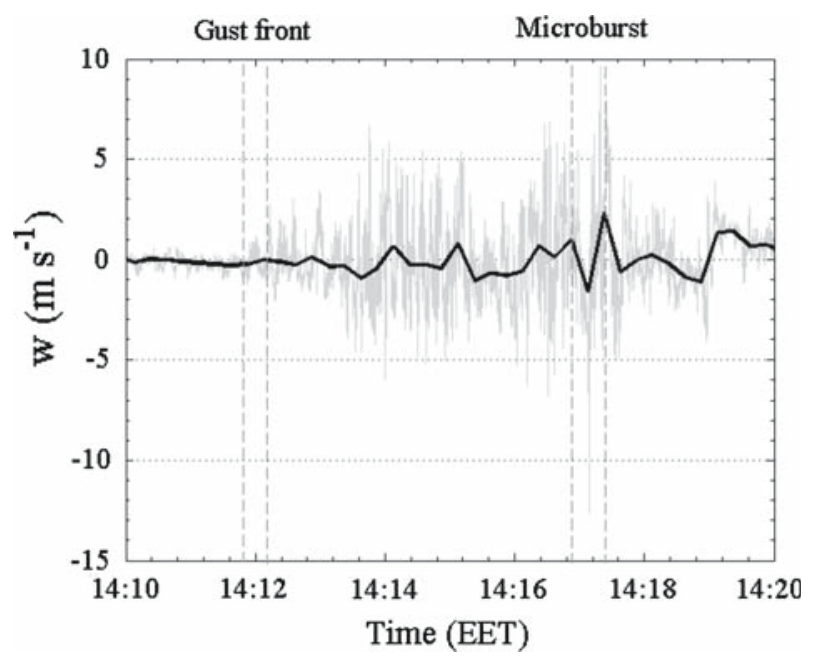

Fig. 6 Time series at location A at SMEAR II station for 1410-1420 EET: instantaneous (grey line) and 15 -sec average (black line) vertical wind speed $\left(\mathrm{m} \mathrm{s}^{-1}\right)$. The vertical dashed lines represent the passage of the gust front and the microburst, respectively

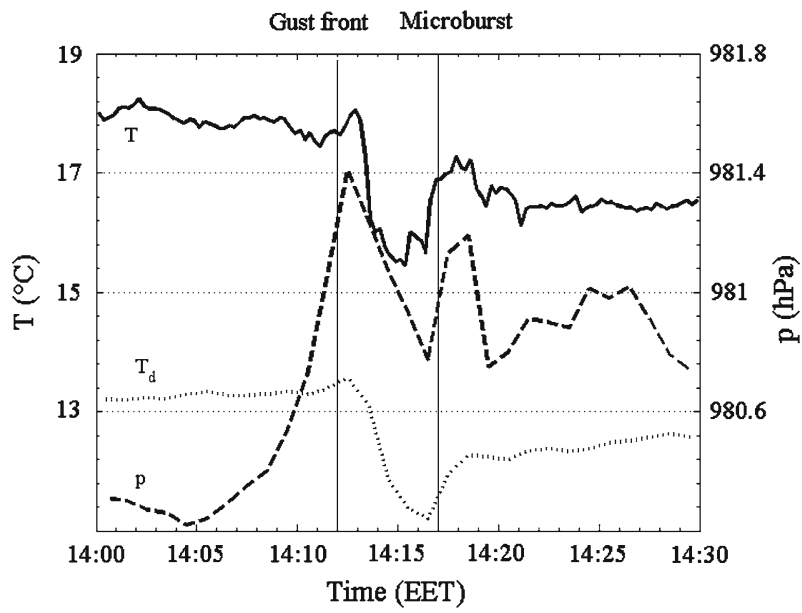

Fig. 7 Time series at location A at SMEAR II station for 1400-1430 EET: 15-sec average temperature at a height of $23 \mathrm{~m}\left({ }^{\circ} \mathrm{C}\right.$, solid line), 1-min average dew-point temperature at a height of $23 \mathrm{~m}\left({ }^{\circ} \mathrm{C}\right.$, dotted line), and 1-min average pressure at the ground $(\mathrm{hPa})$. The vertical lines represent the arrival of the gust front and microburst, respectively

vertical winds stayed gusty (Figs. 4-5), consistent with meteorological measurements from other microburst studies (e.g., Wakimoto 1982; Fujita 1985, his Fig. 6.42).

The measured wind speed maxima of 21 and $22 \mathrm{~m} \mathrm{~s}^{-1}$ at locations A and B, respectively, are consistent with maximum wind peaks from other studies. Ohno et al. (1994) measured a peak wind speed of $26 \mathrm{~m} \mathrm{~s}^{-1}$, whereas lower wind speed maxima of 15 and $10.5 \mathrm{~m} \mathrm{~s}^{-1}$ were measured by Sherman (1987) and Takayama et al. (1997), respectively. The majority of microbursts measured during the JAWS experiment had wind speed maxima between 12 and $16 \mathrm{~m} \mathrm{~s}^{-1}$ (Wakimoto 1985). A two-peaked wind speed maximum, which was most apparent 


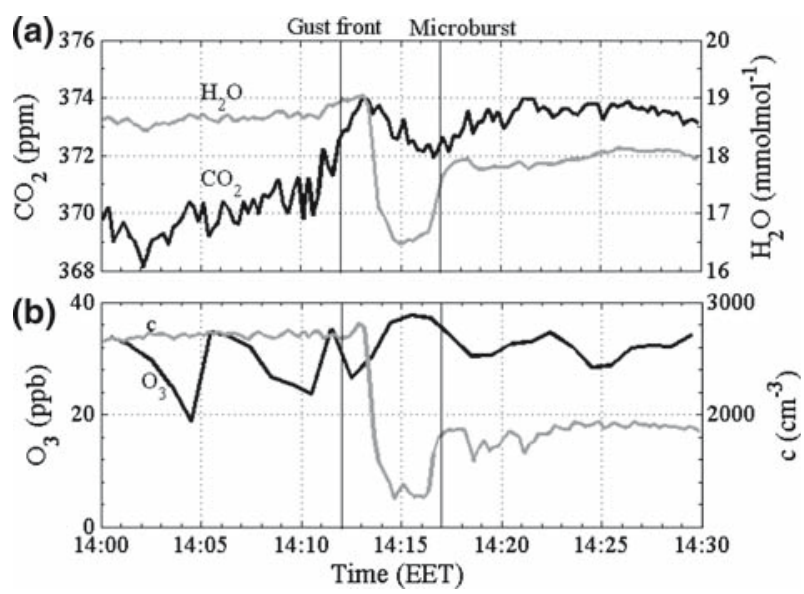

Fig. 8 Time series at location A at SMEAR II station for 1400-1430 EET: (a) 15-sec average carbon dioxide (ppm, black line) and water vapour ( $\mathrm{mmol} \mathrm{mol}^{-1}$, grey line) concentrations, and (b) 1-min average ozone (ppb, black line) and $15-\mathrm{sec}$ average total particle $\left(\mathrm{cm}^{-3}\right.$, grey line) concentrations. The vertical lines represent gust front and microburst, respectively

at location A, is consistent with an observed and modelled wind speed maximum just after the gust front and another maximum close to the downdraft (e.g. Charba 1974; Mitchell and Hovermale 1977).

In addition to the period of downward motion during the microburst, the vertical wind speed showed several brief periods of downward and upward motion between 1412 and 1418 EET (Fig. 6). Mueller and Carbone (1987) showed a similar periodic pattern in vertical wind speeds behind the gust front. Around the time of the strong downward motion during the microburst at 1417 EET, periods of upward motion occurred. These could be caused by vortices formed at the front and rear flanks of the strongest downward motion. Sherman (1987) observed similar behaviour in time series of vertical wind speed from a microburst in Australia.

The forest damage was most probably caused by the powerful microburst around 1417 EET when the wind speeds were strongest (Fig. 4). Based on prior experience in Finland, the small patch of downed trees in the forest would imply the wind speed was about $30 \mathrm{~m} \mathrm{~s}^{-1}$. Such estimated wind speeds are about $10 \mathrm{~m} \mathrm{~s}^{-1}$ higher than the maximum wind speed values at the above-canopy locations, suggesting that the microburst did not directly strike the observing instrumentation.

The wind direction was similar at both above-canopy measurement locations but had somewhat larger fluctuations at the sub-canopy where enhanced turbulent production occurs (Fig. 4c). In contrast, the horizontal wind speeds were over $10 \mathrm{~m} \mathrm{~s}^{-1}$ smaller, and the vertical wind speed was $10 \%$ less at the sub-canopy location than at the above-canopy location.

\subsection{Gas and aerosol particle characteristics}

The data collected during the microburst at Hyytiälä provide a unique opportunity to observe gas and aerosol properties at ground level during such an extreme event. Carbon dioxide concentrations $\left(\mathrm{CO}_{2}\right)$ increased from 370 to $374 \mathrm{ppm}$ at the time of the gust front (Fig. 8a) due to strong mixing of the surface-layer air with the overlying boundary-layer air. When descending cold air arrived at the measurement site and rain started at 1413 EET, the water 
vapour concentrations decreased from 19 to $16 \mathrm{mmol} \mathrm{mol}^{-1}$ in two minutes (Fig. 8a), consistent with the decrease in dew-point temperature (Fig. 7). The effect of the rain scavenging was clear as the total particle concentration decreased from 2800 to $1200 \mathrm{~cm}^{-3}$ during the event (Fig. 8b). The ozone concentration did not have a distinct pattern between 1400 and 1430 EET, although the concentration rose during the microburst (Fig. 8b), consistent with the mid-tropospheric source region of the microburst where higher ozone concentrations occur.

Before the microburst, the aerosol number size distribution was dominated by Aitken and accumulation mode particles (Fig. 9a). The total number concentration was of the order of a few thousand, and positive and negative ion concentrations varied between 400 to 1000 (Fig. $9 b)$. Concurrent with the microburst event (1410-1420 EET), the sub-micron aerosol size distribution was dominated by ultra-fine particles $(<10 \mathrm{~nm}$ in diameter) (Fig. 9a). The total number concentration, together with the negative ion concentrations, increased an order of magnitude at the time of the gust front (Fig. 9b). After the peak, a decrease in total aerosol concentrations occurred, similar to Fig. $8 \mathrm{~b}$. The peak in the number concentration did not occur in Fig. 8b since the detection limit of the CPC (approximately $10 \mathrm{~nm}$ ) is higher than the detection limit of the DMPS. The ion concentration did not decrease due to the rain, but fluctuated rapidly, likely due to the production of intermediate ions during rain (Hirsikko et al. 2007).

Previously, increased number concentration of ultra-fine particles has been measured in relation to clouds. Perry and Hobbs (1994) detected increased concentrations of ultrafine particles in the clean marine air at the level of the anvil outflow. Also Clarke et al. (1998) observed new particle formation in cloud outflow. Highest formation rates were associated with elevated concentrations of sulphuric acid due to enhanced photochemical activity and lower pre-existing particle surface concentration. Keil and Wendisch (2001) detected ultra-fine particles over western Europe, and observed bursts of newly formed particles in the cloud-free air at cloud top. These observations could explain the increased number concentration of ultra-fine particles in the microburst air. Another possible explanation of concurrent high concentrations of ultra-fine particles and ions is the production of charged particles associated with rain (Laakso et al. 2006), although the aerosol and ion sizers were not fast enough to capture the full variability of concentration during the microburst.

\subsection{Turbulence spectra and turbulent kinetic energy (TKE)}

The power spectra of $u_{\text {rot }}$ and $w$ were calculated for 5- to 10-min periods before, during and after the microburst at location A. Before the microburst (1355-1405 EET), the prevailing wind direction was $314^{\circ}$, the average wind speed was $2.0 \mathrm{~m} \mathrm{~s}^{-1}$ and the atmosphere was stably stratified. During the microburst event (1413-1418 EET), the wind direction was $071^{\circ}$ and the average wind speed was $11.1 \mathrm{~m} \mathrm{~s}^{-1}$. Calculating the thermal stability during the event was not possible due to the nonstationarity of the situation. After the microburst (1425-1435 EET), the wind direction was $206^{\circ}$, the wind speed was $2.8 \mathrm{~m} \mathrm{~s}^{-1}$ and the atmosphere was slightly stable. The power spectra were normalized by the variances of $u_{\text {rot }}$ and $w$, smoothed over logarithmically changing frequency intervals, and plotted as a function of normalized frequency $n=f(\bar{z}-d) / \bar{U}$, where $\bar{z}$ is measurement height, $d$ is the displacement height assumed here as $2 / 3$ the average tree height and $\bar{U}$ is the average wind speed (Fig. 10), with the predicted $-2 / 3$ power law for the inertial subrange also shown. The turbulence dissipation rates were calculated before, during and after the microburst for the frequency range $0.5-3 \mathrm{~Hz}$ according to Eq. 1 . 

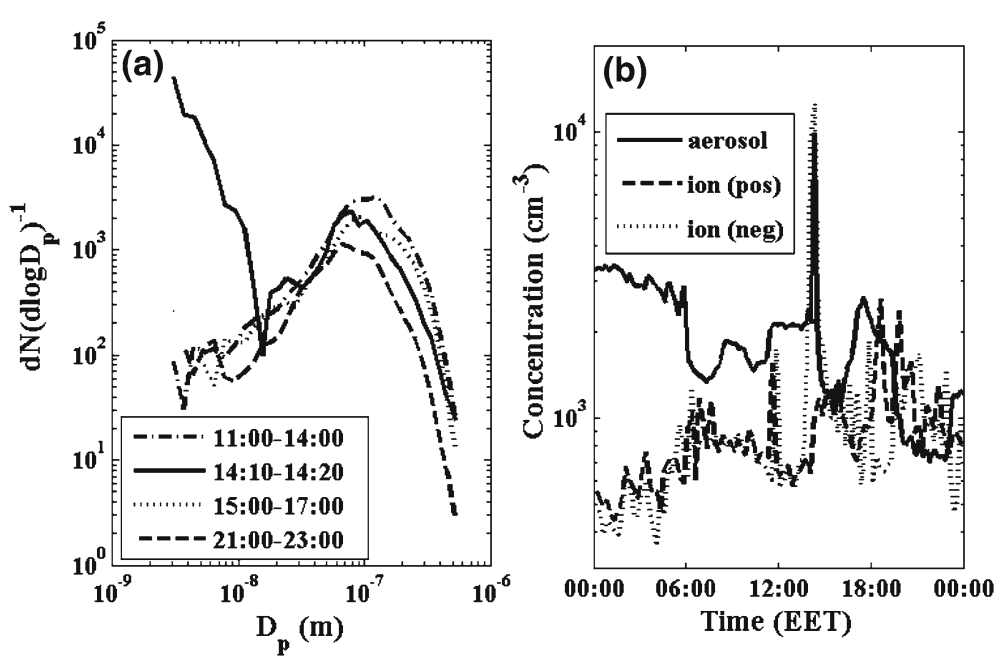

Fig. 9 (a) Observed aerosol number size distributions at location A at SMEAR II station before (1100-1400 EET, dashed-dotted line), during (1410-1420 EET, solid line) and after (1500-1700 EET, dotted line; 21002300 EET, dashed line) the microburst event. (b) Time series at location A at SMEAR II station from 0000 EET 3 July 2004 to 0000 EET 4 July 2004: total aerosol number concentration ( $\mathrm{cm}^{-3}$, solid line), positive ion concentration $\left(\mathrm{cm}^{-3}\right.$, dashed line), and negative ion concentration $\left(\mathrm{cm}^{-3}\right.$, dotted line)

The power spectra of $u_{\text {rot }}$ before and after the microburst showed comparable behaviour (Fig. 10a), both having two maxima around 0.01 and $0.1 \mathrm{~Hz}$. The power spectrum during the event differed from the other spectra in the low-frequency end (below $0.01 \mathrm{~Hz}$ ), with a faster roll-off at lower frequencies during the event indicating less energy in larger eddies. All spectra followed the $-2 / 3$ power law in the inertial subrange. Before and after the microburst, the dissipation rates were below $0.01 \mathrm{~m}^{2} \mathrm{~s}^{-3}$. During the microburst, the dissipation rate of turbulent energy increased substantially to $0.60 \pm 0.02 \mathrm{~m}^{2} \mathrm{~s}^{-3}$. As with the power spectra of $u_{\text {rot }}$, the power spectra of $w$ were very similar in all three cases (Fig. 10b), with a maximum at frequencies $0.05-0.1 \mathrm{~Hz}$ and followed the $-2 / 3$ power law well in the inertial subrange. As with the power spectra of $u_{\text {rot }}$, the greatest differences between these three cases appeared at the low-frequency end, although, in the case of the power spectra of $w$, the before- and after-microburst periods had less energy than the during-microburst period. The reason for the different behaviours of the spectra of $u_{\text {rot }}$ and $w$ at the low-frequency end is not known. Also the reliability of the spectra at the low-frequency end is questionable due to the short calculation periods. Overall, both the spectra of $u_{\text {rot }}$ and $w$ followed typical model spectra before, during and after the microburst event.

The turbulent kinetic energy (TKE) at all three measuring locations was calculated for 15-sec time periods during 1400-1430 EET 3 July 2004 (Fig. 11). TKE was less than $0.1 \mathrm{~m}^{2} \mathrm{~s}^{-2}$ above the canopy and less than $0.01 \mathrm{~m}^{2} \mathrm{~s}^{-2}$ at the sub-canopy before the gust front arrived. About two minutes before the gust front arrived, TKE at all locations increased. By the time of the microburst at 1417 EET, the peak TKE values were greater than $24 \mathrm{~m}^{2} \mathrm{~s}^{-2}$ above the canopy and $5 \mathrm{~m}^{2} \mathrm{~s}^{-2}$ at the sub-canopy. At all measurement locations, TKE had a two-peaked maximum at the time of the microburst (1416-1418 EET), with lower values at 1417 EET when the highest horizontal values were measured. This implies greater flow fluctuations in the vortices along the front and rear flanks of the strongest downward motion. 

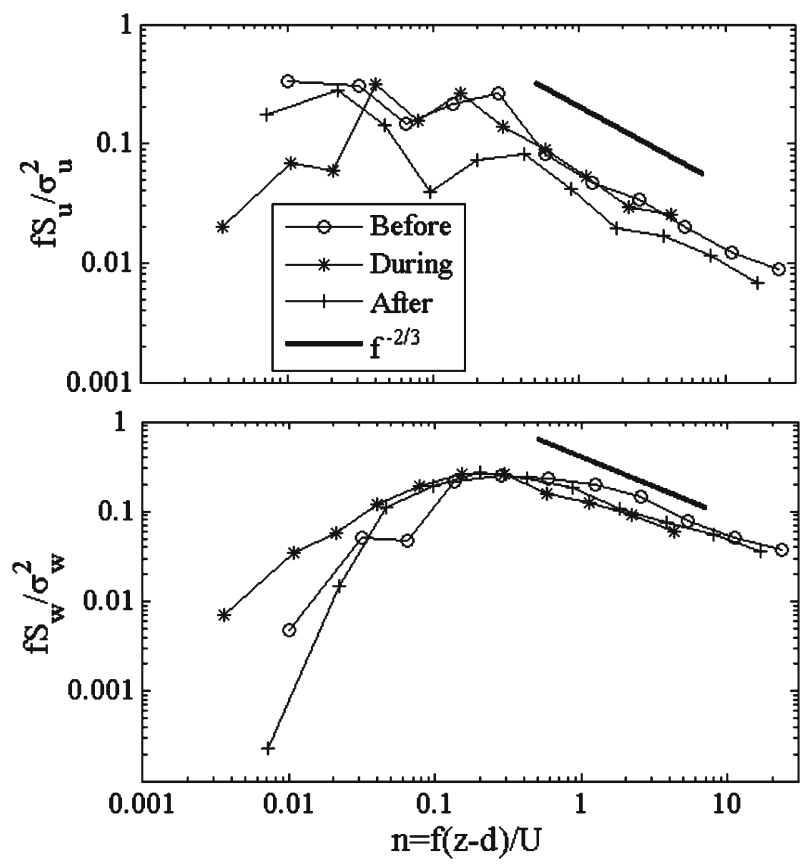

Fig. 10 The turbulence spectra of (a) wind $u_{\text {rot }}$ component and (b) vertical wind velocity $w$ before (13551405 EET), during (1413-1418 EET) and after (1425-1435 EET) the event. Black line shows the $-2 / 3$ power law in the inertial subrange

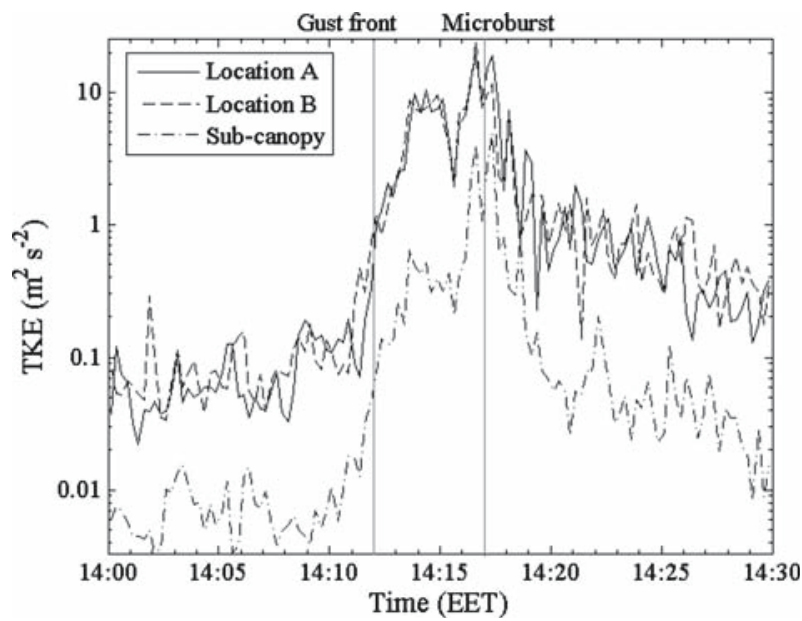

Fig. 11 Time series of turbulent kinetic energy (TKE, $\mathrm{m}^{2} \mathrm{~s}^{-2}$ ) at SMEAR II station for 1400-1430 EET measured above-canopy at locations A and B and sub-canopy. The vertical lines represent the arrival of the gust front and microburst, respectively 


\section{Conclusions}

Severe thunderstorms mainly occur in Finland during the late summer, and forest damage caused by downbursts or tornadoes takes place almost every summer. The event at Hyytiälä on 3 July 2004 caused forest damage next to the SMEAR II field station, providing a unique opportunity to analyze the micrometeorology of a microburst and its attendant gust front. The leading edge of a squall line was reached Hyytiälä at 1330 EET, and the radar reflectivity factor maximum was located in the middle of the line, contrary to observations of other mesoscale convective systems (e.g., Parker and Johnson 2000). Typical radar signatures of downburst-producing convective systems (bow echo, rear-inflow jet, and rear-inflow notch) were observed just north of Hyytiälä preceding and at the time of the microburst. Also, a possible mesovortex was observed in the radar radial velocity data. The individual convective cells moved to the west or west-south-west. Based on the damage, the wind speed was estimated to be around $30 \mathrm{~m} \mathrm{~s}^{-1}, 10 \mathrm{~m} \mathrm{~s}^{-1}$ more than the measured wind-speed maxima.

Micrometeorological data above the canopy at a height of $23 \mathrm{~m}$ (locations A and B), and sub-canopy at a height of $3 \mathrm{~m}$, were used. The horizontal and vertical wind speeds, wind direction, temperature and pressure showed behaviour typical of a thunderstorm outflow (Charba 1974; Mueller and Carbone 1987). An increased number of ultra-fine particles were measured during the gust front. Carbon dioxide concentrations increased due to the stronger turbulent mixing associated with the gust front, and water vapour and particle concentrations decreased due to cold downdrafts and rain. Strong peaks in horizontal wind speeds (21-22 $\mathrm{m} \mathrm{s}^{-1}$ above the canopy and $9 \mathrm{~m} \mathrm{~s}^{-1}$ at sub-canopy) and periods of downward vertical motion occurred five minutes after the arrival of the gust front. Simultaneously, temperature, dew-point temperature, water vapour and pressure increased, suggesting a strong microburst. During the 7-min windy period during the event, the vertical wind speed at location A experienced maxima of upward and downward flow (10 and $15 \mathrm{~m} \mathrm{~s}^{-1}$, respectively), comparable with other microburst studies (e.g., Proctor 1988; Hjelmfelt et al. 1989).

The turbulence spectra of horizontal and vertical wind speeds showed typical model spectral behaviour before, during and after the microburst, with the $w$ spectra following the $-2 / 3$ power law closer than the $u_{\text {rot }}$ spectra in the inertial subrange. The dissipation of turbulent kinetic energy increased during the microburst, with TKE having maxima during the microburst (1416-1418 EET), but values were higher around the measured wind-speed maxima (1417 EET) indicating the front and rear flanks of the strongest downward motion.

Acknowledgements We would like to thank the Academy of Finland and project REBECCA (Helsinki Environment Research Centre) for financial support. Antti Mäkelä, Vesa Nietosvaara and Markus Peura from Finnish Meteorological Institute and Ivan Mammarella, Anne Hirsikko, Heikki Junninen and Samuli Launiainen from University of Helsinki are acknowledged for their help in this study.

\section{References}

Aalto P, Hämeri K, Becker E, Weber R, Salm J, Mäkelä JM, Hoell C, O’Dowd C, Karlsson H, Hansson H-C, Väkevä M, Koponen I, Buzorius G, Kulmala M (2001) Physical characterization of aerosol particles during nucleation events. Tellus 53B:344-358

Atkins NT, Wakimoto RM (1991) Wet microburst activity over the southeastern United States: implications for forecasting. Wea Forecast 6:470-482

Atkins NT, Arnott JM, Przybylinski RW, Wolf RA, Ketcham BD (2004) Vortex structure and evolution within bow echoes. Part I: Single-doppler and damage analysis of the 29 June 1998 derecho. Mon Wea Rev 132:2224-2242 
Atkins NT, Bouchard CS, Przybylinski RW, Trapp RJ, Schmocker G (2005) Damaging surface wind mechanisms within the 10 June 2003 Saint Louis bow echo during BAMEX. Mon Wea Rev 133:2275-2296

Charba J (1974) Application of gravity current model to analysis of squall-line gust front. Mon Wea Rev $102: 140-156$

Choi ECC (2004) Field measurement and experimental study of wind speed profile during thunderstorms. J Wind Eng Ind Aerodyn 92:275-290

Clarke AD, Varner JL, Eisele F, Mauldin RL, Tanner D, Litchy M (1998) Particle production in the remote marine atmosphere: cloud outflow and subsidence during ACE 1. J Geophys Res 103:16397-16409

Droegemeier KK, Wilhelmson RB (1987) Numerical simulation of thunderstorm outflow dynamics. Part I: Outflow sensitivity experiments and turbulence dynamics. J Atmos Sci 44:1180-1210

Evans JS, Doswell CA III (2001) Examination of derecho environments using proximity soundings. Wea Forecast 16:329-342

Fujita TT (1979) Objectives, operation and results of project NIMROD. Preprints, 11th conference on severe local Storms, Kansas City, MO, Amer Meteorol Soc 259-266

Fujita TT (1985) The Downbursts-microburst and macroburst. SMRP researcher paper number 210, University of Chicago, Department of the Geophysical Sciences, pp 60-118

Hari P, Kulmala M (2005) Station for measuring ecosystem-atmosphere relations (SMEAR II). Boreal Env Res 10:315-322

Hirsikko A, Bergman T, Laakso L, Dal Maso M, Riipinen I, Hõrrak U, Kulmala M (2007) Identification and classification of the formation of intermediate ions measured in boreal forest. Atmos Chem Phys 7:201-210

Hjelmfelt MR, Orville HD, Roberts RD, Chen JP, Kopp FJ (1989) Observational and numerical study of a microburst line-producing storm. J Atmos Sci 46:2731-2744

Holton JR (1992) A introduction to dynamic meteorology, 4th edn. Academic Press, San Diego, California, pp $120-122$

Kaimal JC, Kristensen L (1991) Time series tapering for short data samples. Boundary-Layer Meteorol 57:187-194

Kaimal JC, Finnigan JJ (1994) Atmospheric boundary layer flows. Oxford University Press, New York, USA, pp 234-240

Keil A, Wendisch M (2001) Bursts of Aitken mode and ultrafine particles observed at the top of continental boundary layer clouds. J Aerosol Sci 32:649-660

Laakso L, Hirsikko A, Grönholm T, Kulmala M, Luts A, Parts T-E (2006) Waterfalls as sources of small charged aerosol particles. Atmos Chem Phys Discuss 6:9297-9314

Mitchell KE, Hovermale JB (1977) A numerical investigation of the severe thunderstorm gust front. Mon Wea Rev 105:657-675

Mueller CK, Carbone RE (1987) Dynamics of a thunderstorm outflow. J Atmos Sci 44:1879-1897

Ogura Y, Liou M-T (1980) The structure of a midlatitude squall line: A case study. J Atmos Sci 37:553-567

Ohno H, Suzuki O, Nirasawa H, Yoshizaki M, Hasegawa N, Tanaka Y, Muramatsu Y, Ogura Y (1994) Okayama downbursts on 27 June (1991) downburst identifications and environmental conditions. J Meteorol Soc Japan 72:197-221

Parker MD, Johnson RH (2000) Organizational modes of midlatitude mesoscale convective systems. Mon Wea Rev 128:3413-3436

Perry KD, Hobbs PV (1994) Further evidence for particle nucleation in clear air adjacent to marine cumulus clouds. J Geophys Res 99:22803-22818

Piper M, Lundquist JK (2004) Surface layer turbulence measurements during a frontal passage. J Atmos Sci 61:1768-1780

Proctor FH (1988) Numerical simulations of an isolated microburst. Part I: Dynamics and Structure. J Atmos Sci 45:3137-3160

Przybylinski RW, DeCaire D (1985) Radar signatures associated with the derecho, a type of mesoscale convective system. Preprints, 14th Conference on severe local storms. Indianapolis, IN, Amer Meteorol Soc, pp 228-231

Przybylinski RW (1995) The bow echo: Observations, numerical simulations, and severe weather detection methods. Wea Forecast 10:203-218

Punkka A-J, Teittinen J, Johns RH (2006) Synoptic and mesoscale analysis of a high-latitude derecho-severe thunderstorm outbreak in Finland on 5 July 2002. Wea Forecast 21:752-763

Sherman DJ (1987) The passage of a weak thunderstorm downburst over an instrumented tower. Mon Wea Rev 115:1193-1205

Smull BF, Houze RA Jr. (1987) Rear inflow in squall lines with trailing stratiform precipitation. Mon Wea Rev 115:2869-2889 
Takayma H, Niino H, Watanabe S, Sugaya J (1997) Downbursts in the Northerwestern Part of Saitama Prefecture on 8 September 1994. J Meteorol Soc Japan 75:885-905

Trapp RJ, Weisman ML (2003) Low-level mesovortices within squall lines and bow echoes. Part II: their genesis and implications. Mon Wea Rev 131:2804-2823

Vesala T, Haataja J, Aalto P, Altimir N, Buzorius G, Garam E, Hämeri K, Ilvesniemi H, Jokinen V, Keronen P, Lahti T, Markkanen T, Mäkelä JM, Nikinmaa E, Palmroth S, Palva L, Pohja T, Pumpanen J, Rannik Ü, Siivola E, Ylitalo H, Hari P, Kulmala M (1998) Long-term field measurements of atmospheresurface interactions in boreal forest combining forest ecology, micrometeorology, aerosol Physics and atmospheric chemistry. Trends Heat, Mass Momentum Transfer 4:17-35

Wakimoto RM (1982) The life cycle of thunderstorm gust fronts as viewed with Doppler radar and rawinsonde data. Mon Wea Rev 110:1060-1082

Wakimoto RM (1985) Forecasting dry microburst activity over the high plains. Mon Wea Rev 113:1131-1143

Wakimoto RM (2001) Convectively driven high wind events. Severe Convective Storms, American Meteorological Society, Boston, MA, pp 255-298

Wakimoto RM, Murphey HV, Nester A, Jorgensen DP, Atkins NT (2006) High winds generated by bow echoes. Part I: Overview of the Omaha bow echo 5 July 2003 storm during BAMEX. Mon Wea Rev 134:2793-2812

Weisman ML, Trapp RJ (2003) Low-level mesovortices within squall lines and bow echoes. Part I: Overview and dependence on environmental shear. Mon Wea Rev 131:2779-2803

Wheatley DM, Trapp RJ, Atkins NT (2006) Radar and damage analysis of severe bow echoes observed during BAMEX. Mon Wea Rev 134:791-806 